\title{
Rural Governance in South Africa: Is there a Place for Neo-Feudalism in a Democracy?
}

\author{
Sibonginkosi Mazibuko \\ University of South Africa (Unisa) , Department of Development Studies, \\ PO Box 2619, Johannesburg, 2000 \\ Email:mazibsg@unisa.ac.za
}

\section{Doi:10.5901/mjss.2014.v5n20p2455}

\section{Abstract}

The governance of rural areas rests with traditional leadership in South Africa. This governance is determined by the fact that land is in the custodian of this traditional leadership. Individual persons cannot own the land. This fact makes land a major instrument of control by those that have this power of controlling the land. In the province of KwaZulu-Natal, South Africa, citizens have been turned into subjects of the Zulu monarch (Ingonyama). Accordingly, the rural people of KwaZulu-Natal cannot by law own the land they occupy. All land is placed under the monarch. This article therefore argues that placing the land under Ingonyama is a neo-feudalist practice that constitutionally deprives the rural poor the right to own land and to better their lives. It is further argued here that this law will only affect the African population in that province while all other racial groups are free to own land privately. Based on the analysis of existing literature, this article aims to show that the democratic dispensation of 1994 in South Africa left the rural people out in terms of property relations. The article concludes by saying that the Ingonyama Trust Act is a perpetuation of Bantustan politics as it applies only to land that formerly constituted the Bantustan of KwaZulu. As a result, this law is most likely to perpetuate rural poverty.

Keywords: poverty, traditional leadership, underdevelopment, neo-feudalism, democracy.

\section{Introduction}

The 1994 South African democratic dispensation came as a miracle after decades of colonial and settler-colonial rules. In both instances, the African populations had been subjected to various forms of discrimination and oppression. The year 1994 represents a watershed in the history of South Africa. A peaceful transition was made from years of oppression to freedom for all, with the exception of the African rural inhabitants who have actually been constitutionally denied the freedom to individually own property. To illustrate this point, the province of KwaZulu-Natal is chosen for analysis because that is the province in South Africa where a major part of the political activity regarding constitutional matters takes place. Since 1992, constitutional talks with regard to the position of the Zulu monarch in particular and traditional leadership in general in South Africa, have never stopped. This article argues that the (provincial) constitution relegates the rural African people to perpetual poverty by placing the land under the KwaZulu-Natal Ingonyama, in terms of the Ingonyama Trust Act No. 3KZ of 1994.

The objective of this article is to show how that political process prejudices the rural people in South Africa. It is therefore not simply a paper on land reform, but speaks to agrarian reform per se. Cousins (2006, p232) explains the distinction between agrarian and land reform as follows:

\begin{abstract}
Land reform must be clearly distinguished from agrarian reform. The former is concerned with rights in land, and their character, strength and distribution, while the latter is concerned with a broader set of issues: the class character of the relations of production and distribution in farming and related enterprises, within both local and non-local markets. It is thus concerned with economic and political power and wealth and the connections between them; its central focus is the political economy of land, agriculture and natural resources ...
\end{abstract}

It must be pointed out here that no suggestion is being made that governance by chiefs (traditional leadership or whatever it is called today) is unique to South Africa. The system is prevalent in many other parts of the continent, and the world as well. But that does not mean it is always the best thing to do. In fact, history shows that many societies went through this kind of governance, and as societies developed, they discarded it. And, in the South African situation, it has proved that the system is not in the developmental interests of the indigenous people. For too long, the system was used to subjugate the African people to colonial and settler-colonial rules. Over that period it lost legitimacy in the eyes of the governed. It is therefore doubtful that chieftaincy can ever be made to be like it was before colonialism. It also definitely 
cannot be believed that returning to pre-colonial situations is the thing to do.

\section{A Brief Profile of the Province of KwaZulu-Natal}

KwaZulu-Natal is one of South Africa's nine provinces. The province constitutes eight per cent of the total area of South Africa (92,100 of the total 1,219,090 square kilometres of South Africa) and is bordered by the Indian Ocean in the east, Mozambique and Swaziland in the north, Lesotho in the west and the Eastern Cape in the south.

According to the 2001 Census, KwaZulu-Natal comprises 21\% of the total population of South Africa. Of this figure, $85 \%$ is African, with $8.5 \%$ Indian, $5.1 \%$ white and $1.5 \%$ coloured people. Furthermore, $65 \%$ percent of the population living in rural areas is African, while $8.9 \%$ is coloured, $6.9 \%$ white and $2.9 \%$ Indian. In that province, the African population lives mostly in areas that used to be part of the Bantustan of KwaZulu (now KwaZulu-Natal) during the apartheid era.

In this province, poverty and inequality are highest among the African people. The KwaZulu-Natal Department of Economic Development and Tourism (2002) indicates that 74\% of the population lives below the poverty line, relying on remittances, pensions and other state grants as sources of their livelihoods. Of this figure, $62 \%$ is African - quite an increase from the $54 \%$ in 1996. In addition, $40 \%$ of the African population is unemployed, $58.4 \%$ of which are women. Of those who have incomes, whites earn seven times more than the Africans do. The major characteristic of the rural population in KwaZulu-Natal is the lack of access to agricultural land, a fact that contributes to high levels of malnutrition.

Added to the woes of the province of KwaZulu-Natal is the HIV and AIDS epidemic. In 1992, when the country's infection rate was 14\%, the rate in KwaZulu-Natal was more than $18 \%$, and $35 \%$ of orphans was attributed to AIDS (Bradshaw, et al 2000).

\section{KwaZulu-Natal within the Wider Context of the South African Land Issue}

Land dispossession is a historical fact in South Africa. Particularly the African people, in every region of the country, have been victims of land dispossession which logically led to political oppression and economic exclusion. In this respect KwaZulu-Natal was no exception. Structures of chieftaincy, or neo-feudalism as it is referred to in this article, applied to all indigenous people and everywhere that colonialism had left its marks. The only differences lay in degrees.

It was only during the political negotiations of the 1990s' that the Bantustan of KwaZulu chose to advocate for a federal state in South Africa (Human Rights Watch, 1993). The bloodshed that accompanied the whole negotiation process, and demands for recognition of the Zulu monarch were the only factors that made KwaZulu-Natal appear to be different from the rest of the former bantustans. In fact, to this day, all the tribes still have their own traditional leaderships. However, the history of nationalism shows that, had the development process not been interrupted by colonialism, the country would, at some stage, have united under one political leadership from one of the tribes that existed then (Mabutla, 2001). Consequently, the national Traditional Leadership and Governance Framework Act (Act No 41 of 2003), applies to all rural African people. As a result, all traditional leaders are accommodated in both the National House of Traditional Leaders and the Provincial Houses of Traditional Leaders as provided for in section 212 (2)(a) of the Constitution.

The land tenure reform legislation that is most appropriate here is the Communal Land Rights Act 11 of 2004 (CLaRA), and the KwaZulu-Natal Ingonyama Trust Act 3 of 1994. The CLaRA governs all rural communally held lands under traditional leaders, which falls under the Ingonyama Trust Land. Significantly, land tenure reform in rural KwaZuluNatal is approached differently to the rest of rural South Africa. Rural KwaZulu-Natal refers here to all the areas that were part of the settler-colonial KwaZulu Bantustan prior to 1994 (Mazibuko 2010, p183). Chapter 9 of the CLaRA makes special provision for the KwaZulu-Natal rural areas. All such areas in KwaZulu-Natal are governed by the Ingonyama Trust $^{1}$, and are therefore referred to as the Ingonyama Trust Land. All the Ingonyama land is administered by means of the KwaZulu-Natal Ingonyama Trust Act 3 of 1994. This law places all the powers and authority of land administration in the hands of the Ingonyama. Individuals do not have title deeds to this land - it is vested in the Ingonyama. As they have no title deeds, they cannot sell the land. It is in the light of this that Mazibuko (2010) argues that institutions have a special role in the development of a people in particular in the manner they govern the capital assets at people's disposal.

\footnotetext{
1 Ingonyama means king/monarch, and in this particular instance land belongs to the Zulu monarch, not to individual citizens of the land who only have user rights.
} 


\section{Constitutional Denial of Freedom: Entrenching Neo-Feudalism}

In this article, the concept of neo-feudalism will be employed as a model of social construct to explain poverty where the rural poor of South Africa live, particularly in the province of KwaZulu-Natal. The article will also indicate the characteristics of neo-feudalism as found in practice. Given the difficulty experienced in locating a proper definition of the term "neo-feudalism", this article will provide a definition upon which to work. To this effect, neo-feudalism is hereby defined as a system of communal land ownership vested in traditional leadership in a democratic unitary non-feudal society. In such a society, ordinary individual members have no right to privately own the land; they cannot, by law, have title deeds nor sell the land they live on.

The situation is referred to as neo-feudal because, while it contains elements of a feudal society of Western Europe during the Middle Ages (Bloch 1962, pp72 -167), and probably elsewhere in the world, it is found in a democratic, non-feudal (South African) society. Feudalism was characterized by landownership being the supreme method of determining social relations. Today South Africa is a democratic country governed by a very liberal constitution that grants its citizens almost every freedom possible. However, the constitution binds the rural people to a land tenure system which subjects them to chiefs. All rural land belongs to the "monarch", the Ingonyama (read paramount chief). By law, the people living on that land cannot own any part of it in terms of individual private ownership, and consequently cannot have title deeds to that land. The Ingonyama, based on custom and tradition, is the custodian of all rural land. Indigenous people have always held land communally. Besides these two concepts, no other reasons are advanced to justify land deprivation to the poor, rural masses.

Ferguson $(1994, \mathrm{p} 18)$ points out that the system of land tenure in rural areas poses an obstacle to transforming the society. The rural areas are already part of the capitalist mode of production and, in fact, were used by both colonial and settler-colonial administrations as labour reservoirs for the mines and cities. As a result, the concept of transition from agrarian social relations to capitalist private property is of limited value in this situation. The South African society is highly integrated into the capitalist economic system. No part of the country remains untouched by capitalism. As is the case in any capitalist democracy, the Constitution of South Africa, 1996, states that all people have a right to private ownership of property

The second characteristic of neo-feudalism is the system of hereditary chieftaincy, which, once again, is perpetuated on the grounds that it is customary and traditional to have these institutions. The chiefs function as heads of tribes or clans as found all over rural KwaZulu-Natal. The chiefs, like the Ingonyama, draw their salaries from the public purse. To crown the situation, their roles, or job descriptions, are neither clear nor different from that of a police officer. The traditional leaders also realize the fact, as pointed out by one inkosi (chief) Hlengwa in a parliament speech in Cape Town (www.ifp.org.za), that legislation renders the institution of traditional leadership no different from the activities of any non-governmental organization (NGO). Why duplicate services and institutions if the resources could be applied in another important quarter? As indicated in the introductory paragraphs, the province of KwaZulu-Natal is a very poor province. The money wasted on maintaining the neo-feudal system could be utilised in other crucial areas. The State bill to pay for the useless, outdated "customary and traditional" roles could go a long way towards reducing the country's foreign debts and addressing the developmental needs of the people such as poverty, unemployment and inequality.

The KwaZulu-Natal Ingonyama Trust Act No. 3KZ of 1994 placed all the rural land of the former Bantustan in the hands of tribal leadership. On the other hand, all townships that had been part of that Bantustan were excluded from the Ingonyama land. In a democracy, it would be expected that the inhabitants concerned should have a say, for example in the form of a referendum, in the manner in which they wish to be governed. It is my view, therefore, that the "political settlement" reached for KwaZulu-Natal lacks accountability, which is one of the pillars of democracy.

In view of the above, the following questions seem quite in order:

1. Is the "Zulu monarch" capable of accountability?

2. Does the "Zulu monarch" have the (economic) resources to respond to the needs of the people?

In spite of the now worldwide recognition of the fundamental importance of access to productive land to alleviate poverty, the rural poor in South Africa are being denied that opportunity. Instead, the rural poor - women and children in particular - will continue to carry the burden of landlessness. At the same time the males and the young people will continue providing migrant labour to the cities, the old practice with all its attendant consequences such as family breakdowns and putting pressure on limited social services like housing, health and education in urban areas (Nel 2005, p253).

Constitutionally, all South African citizens have the right to stay and own property wherever they wish. But the people in KwaZulu-Natal have been denied that constitutional right. The rural poor will continue to live on "borrowed" land that they can neither buy nor sell since it belongs to the paramount chief - the Ingonyama. These rural people have, in 
fact, been disenfranchised in terms of landownership. In South Africa it is easier for foreigners to buy land and own it privately than it is for the indigenous people to have access to their own land as a birthright. At the same time, the white farmers who live adjacent to the rural black communities have landownership rights of the land they occupy, but not the indigenous rural African.

While some external factors stand in the way of development, neo-feudalism represents contradictory internal political and economic power relations and contradictory interests in South Africa. The South African rural poor find themselves in a difficult situation: nationally the political machine is reluctant to function and locally the tribal ideologues and the elite are only interested in safeguarding their own interests. Generally, the legislation on traditional leadership poses difficulties in that at the lower (municipal) level of the democratic political administration, land is controlled by chiefs. Issues of who has the final say in such areas and in what manner are currently hotly debated in South Africa (see Ntsebeza 2005). Consequently, development is hampered at that level in the affected areas. To this end, neo-feudalism represents a pillar of rural underdevelopment in South Africa.

There seems to be no other reason to retain and maintain these neo-feudal institutions at the expense of the taxpayer, except that they are traditional and customary. Traditions and customs are inherently good, one should think, as long as they do not become a burden to society. If these institutions could sustain themselves, nobody would probably care whether or not they exist. Those who support the system should produce the means to sustain it themselves. The State would then not be expected to use public money for the benefit of tribal ideologues while the people they purport to represent are starving.

In the South African context, neo-feudalism represents arrested development. While the political elites choose capitalism for themselves, the African rural poor are assigned to poverty-perpetuating conditions of neo-feudalism. The rural poor have been made prisoners of tradition and underdevelopment. Under these conditions, they will continue to "exist" only at election times; at other times they remain subjects of the chiefs and not citizens of the country. They have become constitutionally landless subsistence-farming communities on borrowed land that they cannot dispose of as they wish in order to improve their lot. Instead of traditional and customary status quo relating to land access, rural poverty could be diminished by allowing the rural people control and ownership over land - with the proper title deeds to it. De Soto's (2000) argument about dead capital in the developing world speaks directly to South Africa's neo-feudalism. De Soto argues that the developing world has a large part of its land occupied by people who do not own it and have no title deeds to it. As a result, such land cannot be developed and the country loses revenue. This condition is very typical of the South African situation.

Similarly, South Africa's own policy in the form of the Rural Development Framework (1997, p71) (in Mazibuko 2010, p185) states that

Property rights are important for obtaining capital for investment in entrepreneurial activity - either through selling the asset or getting finance on the strength of it. For many decades, the African population was deprived of this economic opportunity as a result of discriminatory laws which prevented them from owning or leasing land or marketing produce. Among other things, this has stifled business related opportunities

To ensure that the rural poor are not impoverished any further by being deceived into commercially parting with their land, the State could stipulate conditions for how and when their land can be sold in the land market. For example, the State can make it compulsory that every landholder receive training on economic use of the land, and that such land may not be sold before the new owners have lived on it for a minimum period of seven years. During that time, the state can engage in concerted efforts to educate landowners about various modern land practices. That would, of course, require funding, but money spent on such issues for a limited period far outweighs the benefits gained from money spent continuously on government welfare programmes for the alleviation of poverty. Arguments can be raised that such policies could be very expensive, but such expenses are negligible compared with the money spent on short-term goals to address poverty. Large sums of money spent on long-term development goals are more justifiable than large sums spent on short-term objectives, while the state plays a welfare role in a situation where people can, in fact, manage to look after themselves if given the necessary resources.

In the spirit of capitalism, some section of the population, particularly the white people, thrive on individual landownership but rural Africans suffer in abject poverty under the communal landownership system. It is therefore argued here that the rural poor need the constitutional right to individually own the land. Some of the advantages of allowing the rural poor to own land can be the following:

1. The land could be used as collateral to obtain credit from financial institutions, and the credit to improve the areas concerned. The increased value of the land could in turn encourage the owners to look after the 
environment, thereby increasing the value of their properties even further.

2. The land could be leased out in times of hardship when individuals are unable to cultivate it economically themselves. This could ensure owners of a constant income and prevent them from becoming even poorer and destitute. The State would be relieved of the burden of looking after huge numbers of people who "cannot look after themselves". The money saved could be used elsewhere for developmental purposes. Indeed, Webster $(1990$, p21) indicates that government efforts to provide food, warmth and shelter for the poor are merely addressing the symptoms and not the causes of poverty. Webster concedes that what are actually required are attempts towards redistribution of land in favour of the rural people. Land ownership plays a major role in ensuring sustainable livelihoods for the rural people; therefore allowing the South African rural poor access to and ownership of the land will go a long way towards addressing poverty in that country. In the current situation, foreign interests are allowed to own land in South Africa but indigenous people are constitutionally deprived of that right.

3. Landownership has the potential to reduce birth rates. Knowing that they have limited resources, individuals are more likely to opt for smaller families. The joy and freedom from poverty would compel individuals to ensure the same for their families. Since land is a limited resource, people would also limit their procreation habits. The reduced birth rate would lead to reduced population growth. With a smaller population, the carrying capacity of the land would increase, and create better chances for sustainable development.

4. Increased opportunities for protection of the natural environment would be ensured. The economic value of the environment should act as a motivating factor to ensure that the land is well looked after. Because individuals would now reap direct private benefits from a healthy environment, they would regard it as an investment not only for themselves but for their children as well. Considerations regarding population and environment are important because, as the South African Human Development Report (2003, pp26 and 82) indicates, the rural poor are quite aware that, if resources are used indiscriminately in future, the degraded environment would mean less access to the natural resources they depend on for their livelihoods.

5. Private landownership has the potential to ensure political stability. People are assured of secured sustainable livelihoods and are mainly interested in improving their lot instead of forever looking to the state to provide for their upkeep. The state then ceases to be a welfare institution and scarce state resources can be applied in other more needy areas.

6. Private ownership of land has the potential to ensure food security for rural and urban populations as people become more responsible for their own upkeep. The surplus produce could then be passed on to the urban areas. In this way, the rural people would be allowed the freedom that is only an illusion at present - the freedom from poverty.

7. Park (1992, pp191-198) mentions several other benefits of landownership that accrued to the people of Korea after that country's 1950 land reform policies. One of the benefits was increased education for farmers in particular, which allowed them to access technology. This increased access to education led in turn to higher land productivity and increased use of fertilizers. These increases should therefore be seen as multiplier effects of allowing people to own land.

\section{A Political Blunder or Political Tactics?}

There could be several explanations for the political route chosen for the former bantustans in South Africa. Africa's history is full of bloody secessionist politics. In this case, the South African government could be making attempts to avoid a repeat of the continent's ugly history. The KwaZulu-Natal case could be seen as a political mistake that forced the government to pass legislation that is both politically and economically unsustainable, in order to satisfy the tribal ideologues who always threaten violence if they do not get their way democratically. How else can it be explained that the feudal lords (chiefs) are considered to be politically non-aligned when their very top leadership occupy senior leadership positions in political parties? It is, in fact, the feudal lords that are behind the promulgation of the pieces of legislation such as discussed in this article. Its leadership, backed by the other apartheid political formations at the time of political negotiations in the 1990s, was very vocal in their support of a federation state in South Africa because they preferred 'self-governance' to the unitary state as proposed by the broad liberation movement in the country. Consequently, the supposedly-democratic State has allowed itself to be derailed from a developmental path that had the potential to benefit everyone in the country.

Another explanation for giving in to the demands of the KwaZulu-Natal tribal leadership could be that of political tactics. The national ruling party, the African National Congress (ANC), could be sacrificing the poor rural areas of 
KwaZulu-Natal to the "Zulu monarch" for example, knowing that this monarch will never be able to meet the needs of their subjects. This failure could fuel unpopularity of the "monarch". If it were possible, they could have delivered the required services during the apartheid era when they had all the opportunities to develop separately under the Verwoerdian (settler-colonial) model. But instead, the South Africa's rural areas (in the words of Rodney 1972, p233) became the dumping ground for the illiterate, semi-literate, the meek, the unemployed and the unemployable.

The Ingonyama Trust Act is a further political move in that it takes away the urban townships from the "monarchy". In South Africa, townships are known for their political volatility. Township dwellers will not tolerate non-delivery of essential services and are able to bring the whole country to the brink of economic collapse and political turmoil. It is also in the townships where the vocal, liberated African elites live, regardless of tribal origins. With the exception probably of those who have just arrived in the cities and are still vulnerable to tribal inclinations, urban people are more interested in a better and progressive life for themselves and their families. In this sense, the political move is likely to work in favour of the ruling party.

Another view that could be advanced for maintaining the chieftaincy system is what Ferguson (1994) calls the antipolitics machine. As in the colonial/settler-colonial era when the system of chieftaincy was a keystone of British indirect rule and the white supremacy ideology of separate development/apartheid, and therefore underdevelopment, so it is used today to depoliticize the rural areas in South Africa. The neo-liberal policies of the day having failed them, the rural people in KwaZulu-Natal are subjected to neo-feudal depoliticizing machinery that can only worsen inequality between the rural and urban areas as well as between the white people and the black people in the country. It should be borne in mind that the KwaZulu-Natal Ingonyama Trust Act applies only to the rural African populations. This happens in spite of the fact that many people of other racial groups also live in rural areas and in that province in particular.

\section{Conclusion}

It is a fundamental principle of democracy that all people in a country should be treated equally before the law. While this constitutional process is aimed at appeasing the tribal ideologues, it gives rise to many other problems. Subjecting the rural people to the rule of chieftaincy creates elements of discrimination because that law applies only to African people residing in rural areas particularly in KwaZulu-Natal.

There is no basis to believe that the KwaZulu-Natal Ingonyama Trust Act is aimed at helping the country address its developmental needs. On the contrary, by recognising unelected leadership, the Act entrenches neo-feudalism to serve the interests of the elite tribal ideologues. Because of its controversial political importance, the Act should at least have been subjected to a referendum. It should not have been limited to the views of the few elites who purport to be acting in the interests of the people in rural areas. It could therefore be regarded as perpetuating bantustanism politics of depoliticizing and re-tribalizing the rural areas, and promoting neo-feudalism.

\section{References}

Bloch, M. (1962). Feudal society. London: Routledge.

Bradshaw, D., Nannan, N., Laubscher, R., Groenewald, P., Joubert, J., Nojlana, B., Norman, R., Pieterse, D. and Schneider, M. 2000. South African National Burden of Disease Study: KwaZulu-Natal. Medical Research Council: Cape Town.

Cousins, B. (2006). Agrarian reform and the two economies': transforming South Africa's countryside, in The land question in South Africa: the challenge of transformation and redistribution, L Ntsebeza and R Hall (editors). Cape Town: HSRC.

De Soto, H. (2000). The myth of capital: why capitalism triumphs in the west and fails anywhere else. Nwe York: Basic Books.

Dumalisile, S. and White, R.M. (2002). Monitoring and management of indigenous forests fauna using traditional and scientific methods: an Eastern Cape study. Natural forests and Savannah woodlands Symposium111.

Ferguson, J. (1994). The anti-politics machine: "development", depoliticization, and bureaucratic power in Lesotho. London: Minnesota Press.

Hlengwa, M.W. (2003). National Assembly Traditional Leadership Governance Framework Bill Address. www.ifp.org Accessed 23/12/2005.

Human Rights Watch. (1993). "Traditional" dictatorship: One party state in KwaZulu homeland threatens transition to democracy, volume 5, number 12(A) www.hrw.org Accessed 10 February 2007.

Mabutla, F. G. (2001). The fate of traditional leaders in post-apartheid South Africa. www.ecu.edu Accessed 10 February 2007.

Mazibuko, S.G. (2010). Development and pro-poor tourism: the livelihood strategies of AmaZizi in the northern Drakensberg, KwaZuluNatal. Unpublished PhD dissertation. Bloemfontein: University of the Free State.

Nel, E. (2005). Local economic development in South Africa's small towns, in Local economic development in the developing world. E Nel and C M Rogerson (editors). London: Transaction Publishers.

Ntsebeza, L. (2005). Democracy compromised: chiefs and the politics of land in South Africa. Cape Town: HSRC. 
Park, Y.J. (1992). Land tenure and economic efficiency, in Development and democratization in the Third World: myths, hopes, and realities. Edited by K E Bauzon. Washington: Crone Russak.

Rural Development Framework. (1997). Available at www.anc.org.za Accessed 10/03/2009.

Rodney, W. (1972). How Europe underdeveloped Africa. Washington: Howard University Press.

South Africa. (1994). KwaZulu-Natal Ingonyama Trust Act, Act No.3KZ

South Africa. (1996). The Constitution of the Republic of South Africa, Act No. 108.

South Africa. (2001). Census. Statistics South Africa.

South Africa. (2002). KwaZulu-Natal Economic Review. Department of Economic Development and Tourism.

South Africa. (2003). Traditional Leadership Governance Framework Act, Act No. 41 of 2003.

UNDP. (2003). SA Human Development Report: the challenge of sustainable development in South Africa: unlocking people's creativity. www.undp.org.za Accessed 11/05/2004.

Webster, A. (1990). Introduction to the sociology of development, $2^{\text {nd }}$ edition. Macmillan: London. 